\title{
Impact of Soil Fertility Management Practices on Insect Pests and Diseases of Maize in Southwest Cote d'Ivoire
}

\author{
Jacob NANDJUIa, Nahoulé Armand ADJAa, Kouakou Théodore KOUADIOa, Marie-Prisca Adjoafla \\ N'GOUANDIa, Latifou IDRISSOU b \\ a Département de formation et de recherche Agriculture et Ressources Animales, Institut National Polytechnique Félix \\ Houphouët-Boigny BP 1313, Yamoussoukro, Côte d'Ivoire. \\ b International Institute of Tropical Agriculture (IITA), IITA, PMB 5320, Oyo Rd, Ibadan, Nigeria. Permanent address : \\ Faculté d'Agronomie, Université de Parakou. BP : 123 - FA/UP - Parakou, Bénin. \\ Corresponding author: Jacob NANDJUI (jacobnandjui@gmail.com) - BP 1313 Yamoussoukro, Cote d'Ivoire
}

Original submitted in on 20th April 2018. Published online at www.m.elewa.org on $31^{\text {st }}$ July 2018 https://dx.doi.org/10.4314/jab.v127i1.6

\begin{abstract}
Objectives:_Integrated soil fertility management (ISFM) is essential for sustainable management of tropical soils. However, soil fertility management is able to affect plant susceptibility to pests and diseases. The study investigated impact of soil fertilization practices on maize pests and diseases during two identical and simultaneous trials setup in South-West Cote d'Ivoire.

Methodology and Results: Experiments were laid out using complete randomized block designs with three replicates and four treatments: (1) control; (2) chemical fertilization; (3) fertilization with cattle manure; (4) association "maize + legume" combined with chemical fertilization. Overall, 22 insect species collected and two diseases (maize streak disease and curvularia leaf spots) observed at both sites. Only cattle manure clearly increased pest and disease damages. The use of cattle manure significantly increased leaf infestation rate and maize streak disease frequency at both sites. Similar impact of NPK and cattle manure was obtained on maize yields either in monocropping or in mix cropping.

Conclusions and application of findings: This study clearly confirmed that ISFM is able to affect plant susceptibility to pests and diseases. Cattle manure attracted a diversity of insects of diverse functional groups such as air-borne pests. These latter affected some plant parts; in this case, maize leaves which infestation rate significantly increased. This attraction for multitude insects may increase vector-borne diseases such as maize streak which frequency significantly increased at both sites. Consequently, despite the potential of cattle manure to increase maize yield, their use as organic fertilizer requires to take some precautions. So, the promotion of cattle manure as organic fertilizer in substitution of chemical fertilizer in tropical regions where it is available is encouraged. However, it should be converted into compost or pre-treated for optimal use in agriculture. Finally, mix cropping could be suggested for optimization of economic profit.
\end{abstract}

Keywords: Maize, leaf infestation, maize streak disease, soil fertility management, cattle manure 


\section{INTRODUCTION}

Maize is a major staple food crop grown in diverse agro-ecological zones and farming systems, and consumed by people with varying food preferences and socio-economic backgrounds in sub-Saharan Africa (Macauley \& Ramadjita, 2015). In the Nawa region, Southwest Cote d'Ivoire, cocoa, coffee, rubber predominantly occupy arable lands and oil palm and food crops are facing land unavailability. These tree crops lead to high pressure on lands whereas a virtual absence of soil fertility management is noticed (Diby et al., 2014). As a result, soil fertility is declining hence. Food production is the most affected with extensive agricultural currently practiced creating an impasse for food security. Small-scale farmers such as women mainly ensure this food production. Due to land pressure, fallowing is being disappeared while farmers are not sensitized on crop rotation.

Maize is susceptible to a range of pests (Steffey et al., 1999; Jean \& Boisclair, 2009) and diseases (CABI, 2015). In Côte d'Ivoire, various phytophagous and borer insects are able to feed on maize. However, borers are the most common and harmful. The main borers known are Eldana saccharina Walker, Pyralidae, which attacks both stem and cobs, Busseola fusca Fuller, Noctuidae, found mainly in stem and cob borer Mussidia nigrivenella Ragonot, Pyralidae (Pollet et al., 1978; Ortega, 1988; Moyal, 1993; 1998). Others insect-pests like jassids, vectors of streak virus, are among the main causes of crop losses (Moyal, 1988). Maize streak appears to be probably the main viral threat that reaches maize and curvularia leaf spot has been repeatedly encountered (Fauquet \& Thouvenel, 1987; Karavina,

\section{MATERIAL AND METHODS}

Study area and sites: This study was conducted in the Nawa region, Southwest Cote d'Ivoire, where $30 \%$ of the cocoa is produced (Diby et al., 2014). This region is one of the most densely populated of the country mainly because of cocoa economy, which attracts many migrants from other parts of the country and West African countries (Smoot et al., 2013). This has led to strong pressure on arable lands that are mainly devoted to cash crops. The global landscape of the region is very heterogeneous and dominated by agriculture with mosaic of tree crop
2014). Integrated soil fertility management (ISFM) appears as a dire need to address soil nutrient depletion and boost agricultural output in the Nawa region. ISFM is defined as "a set of soil fertility management practices that necessarily include the use of fertilizer, organic inputs and improved germplasm, combined with the knowledge of how to adapt these practices to local conditions, aimed at maximizing agronomic use efficiency of the applied nutrients and improving crop productivity"(Vanlauwe et al., 2010). ISFM allows expanding the choice set of farmers by increasing their awareness of the variety of options available and how they may complement or substitute for one another (Place et al., 2003). ISFM can affect plant susceptibility to pests and diseases by altering plant tissue nutrient levels. Crop plant ability to resist or tolerate insect pests and diseases is tied to optimal physical, chemical and mainly biological properties of soils (Altieri \& Nicholls, 2003). Soils with high organic matter and active soil biology generally exhibit good soil fertility while excessive use of inorganic fertilizers can cause nutrient imbalances and lower pest resistance (Altieri \& Nicholls, 2003). Despite the link between ISFM and integrated pest management, their advancement has proceeded separately. Thereby, it was suggested to increase studies comparing pest populations on plants treated with synthetic versus organic fertilizers are needed (Altieri \& Nicholls, 2003; Place et al., 2003). This paper aims to assess impact of different ISFM options on maize by measuring their effect on incidence of maize pests and diseases.

plantations and food crops (Diby et al., 2014). Agricultural production faces soil fertility constrains depletion that constitutes a real threat for food security. Food crops are grown on very small areas $(<1 \mathrm{ha})$ notably by women for household consumption and for making money. In this context, maize is grown for its high nutrition value, market value and high potential for crop association. Two participatory maize trials were set up in Krohon 1 (05.3453 N; $06.5255 \mathrm{~W} ; 120 \mathrm{~m}$ ) and Krohon 2 (05.3584 $\mathrm{N} ; 06.5249 \mathrm{~W} ; 130 \mathrm{~m})$ that differed by their initial soil nutrient contents (Table 1). 


\section{Nandjui et al, J. Appl. Biosci. 2018 Impact of Soil Fertility Management Practices on Insect Pests and Diseases of Maize in Southwest Cote d'Ivoire}

Table 1: Soil parameters recorded as means \pm standard-errors.

\begin{tabular}{l|l|l|l|l|l|l|l}
\hline Sites & $\mathbf{p H}$ & $\begin{array}{l}\mathbf{C} \\
(\%)\end{array}$ & $\begin{array}{l}\mathbf{N} \\
(\%)\end{array}$ & $\begin{array}{l}\mathbf{P} \\
(\mathbf{p p m})\end{array}$ & $\begin{array}{l}\text { CEC } \\
(\mathbf{c m o l} / \mathbf{k g})\end{array}$ & $\begin{array}{l}\mathbf{C a}^{2+} \\
(\mathbf{c m o l} / \mathbf{k g})\end{array}$ & $\begin{array}{l}\mathbf{K}^{+} \\
(\mathbf{c m o l} / \mathbf{k g})\end{array}$ \\
\hline Krohon 1 & $5.59 \pm 0.01 \mathrm{a}$ & $1.46 \pm 0.15 \mathrm{a}$ & $0.13 \pm 0.01 \mathrm{a}$ & $09.67 \pm 0.27 \mathrm{a}$ & $5.23 \pm 0.76 \mathrm{a}$ & $1.15 \pm 0.12 \mathrm{a}$ & $0.13 \pm 0.00 \mathrm{a}$ \\
Krohon 2 & $5.68 \pm 0.02 \mathrm{a}$ & $0.84 \pm 0.04 \mathrm{~b}$ & $0.08 \pm 0.00 \mathrm{~b}$ & $06.67 \pm 0.88 \mathrm{~b}$ & $3.76 \pm 0.39 \mathrm{~b}$ & $1.02 \pm 0.00 \mathrm{a}$ & $0.10 \pm 0.02 \mathrm{a}$ \\
\hline
\end{tabular}

Experimental design and treatments: Two identical and simultaneous trials were set up at the beginning of the rainy season. Experiments were laid out using a complete randomized block design with three replicates and four treatments on plots of $18 \mathrm{~m}^{2}(4.0 \mathrm{~m} \times 4.5 \mathrm{~m})$ size. Blocks were distant from $3 \mathrm{~m}$ and plots were distant from $2.5 \mathrm{~m}$. Maize variety named $P R 9151$ was sown at a $0.75 \mathrm{~m} \mathrm{x}$ $0.40 \mathrm{~m}$ density with two plants grown per hole. The treatments were: (1) control with no supply in fertilizer and no association with other crop; (2) chemical fertilization consisting in application of NPK (12 22 22) at $150 \mathrm{~kg} / \mathrm{ha}$ before sowing and urea $(46 \% \mathrm{~N})$ at $150 \mathrm{~kg} / \mathrm{ha}$ four weeks after sowing (WAS); (3) organic fertilization consisting in application of cattle manure at about $15,000 \mathrm{Kg} / \mathrm{ha}$ before sowing; (4) association "maize + legume" combined with chemical fertilization. Legume was sowed three WAS using soybean in Krohon 1 and beans in Krohon 2. Two rounds of weeding were systematically performed at four and eight WAS. At four WAS, all plots received a Deltamethrin $(15 \mathrm{~g} / \mathrm{l})$-based insecticide treatment at 0.5 I/ha. The application was performed at 1-3 bar using a pressurized hand backpack sprayer equipped with a $16 \mathrm{I}$ container and a simple nozzle.

Insect sampling and pests infestation evaluation: Field surveys were performed to determine infestation rate of major insect pests. For that purpose, twice a week all parts of maize were examined in each block and collected stages of all insect pests. The number of plants with damages was also determined to estimate infestation rate of different plant parts. In addition to direct observation of insects on different plant parts, we also used pitfalls per plot (Upton et al., 2010). Traps were set up two WAS and consisted in plastic jars containing soapy water and salt renewed all two days. Insects collected were identified and counted. Insects' identification was based on morphology characteristics using a binocular microscope $(G \times 50)$. The observed characteristics were compared with those of lab collection and identification keys (Ortega, 1988; Bordat \& Arvanitakis, 2004; Jean \& Boisclair, 2009; James et al., 2010). Insect damages were evaluated counting plants with leaves, stems and fruits. Leaf infestation rate was assessed at four WAS before insecticide application and stem attacks were assessed 12 WAS through the following calculation: Infestation rate $(\%)=($ Plants attacked/Plants observed) x 100 .

Disease sampling and infection evaluation: Field surveys were performed to examine all parts of maize to record symptom of maize streak disease (Fig. 1.A), fungal diseases, notably curvularia leaf spot (Fig. 1.B).
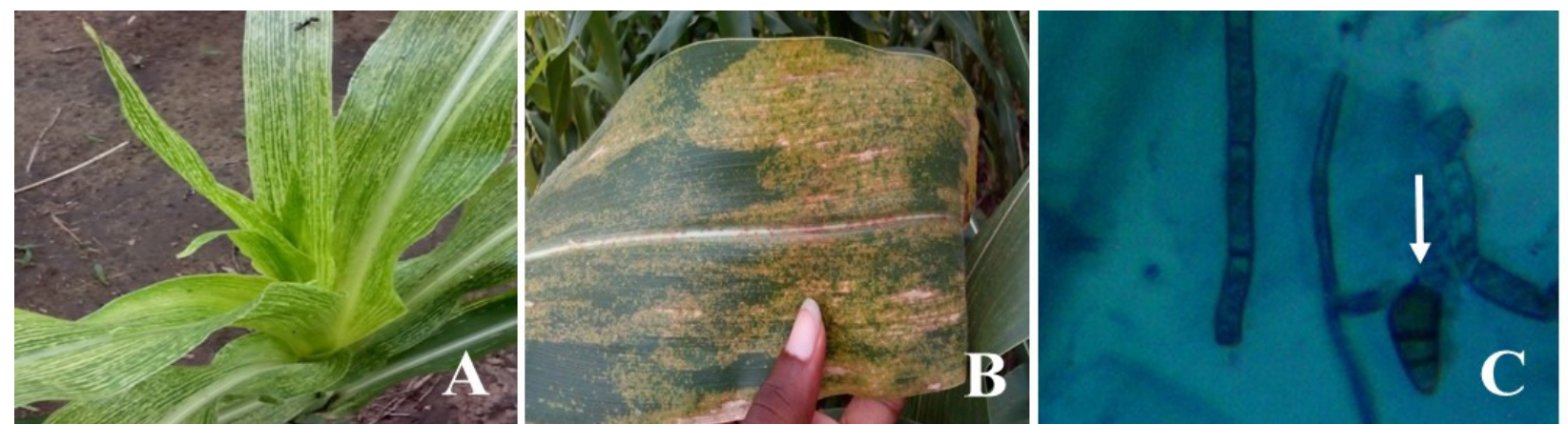

Fig. 1. A. Symptoms of maize streak due to Maize streak virus; B. Curvularia leaf spot; C. Conidia of Curvularia sp. causing leaf spots.

Samples of infected leaves were collected and taken to laboratory for more detailed assessment. Parts of leaf samples located between healthy and infected areas was cut into small pieces, sterilized by immersion in $1 \%$ Sodium Hypochlorite $(\mathrm{NaOCl})$ solution for five minutes and three-time rinsed in sterile distilled water for another three minutes. Thereafter, leaf pieces were air dried for three minutes and put into several Petri dishes $(90 \mathrm{~mm}$ diameter) containing PDA and incubated at $30^{\circ} \mathrm{C}$ for a few days. Fungal colonies growing on leaf pieces were 
purified by transferring again into PDA. After few other days, conidia and mycelium (Fig. 2.C) were identified using a microscope. Disease incidence was evaluated through frequency and severity nine WAS. Disease frequency was calculated by the following formula:

Disease frequency $(\%)=($ Plants infected $/$ Plants observed) $\times 100$.

For severity index, we examined, for each disease, symptom degree on leaves of infected plants based on visual assessment (Welz et al., 1998) as followed: $1=$ no symptom; $2=\leq 25 \%$ leaf area presented symptoms; $3=$

\section{RESULTS}

Insects collected: Twenty-two species distributed into eighteen families and nine orders were identified at both sites (Table 2). Coleoptera was most diversified with seven species followed by Orthoptera (five species), Lepidoptera (three species) and Hymenoptera (two species). Most of species collected have a phytophagous status (Orthoptera, Coleoptera, Lepidoptera, Homoptera, Heteroptera, Diptera and Isoptera) while others are omnivores (Orthoptera and Dictyoptera), predators (Coleoptera and Hymenoptera), coprophagous (Diptera) and virus vectors (Homoptera). These insects were mainly observed at growth stage and during flowering.
$26-50 \%$ leaf area presented symptoms; $4=51-75 \%$ leaf area presented symptoms; $5=76-100 \%$ leaf area presented symptoms. Then we determined the severity index for each block (Kranz, 1998):

Severity index $=\sum(X i \times n i) /(N \times Z) \times 100 .(X i=$ Severity $i$ of disease on the plant; $n i=$ Number of plants with severity $\mathrm{i} ; \mathrm{N}=$ Total number of plants observed; $\mathrm{Z}=5$, highest value of severity).

Data analysis : All data are reported as mean \pm standard errors of three replicates per plot. Data analyses were performed with STATISTICA 7.1 using one-way nonparametric Kruskal-Wallis ANOVA. Significant differences were tested using U-Mann-Whitney test at $p=0.05$.

Helicoverpa zea and Microtermes sp. were observed during fructification. Species richness was 19 and 20 respectively at Krohon 1 and Krohon 2. Homopterous was the most abundant order dominated by Rhopalosiphum maidis at both sites. Chrotogonus senegalensis was also abundant at both sites and followed by Gryllus bimaculatus mainly observed in cattle manure-fertilized plots and "maize+legume" plots (Fig. 2). Pachycondyla sylvestri (Hymenoptera) was fairly well represented at both sites for all the treatments. Unlike the previous species, Delia sp. was observed only on cattle manurefertilized plots.

Table 2: Insects collected on maize during the trials at the two sites.

\begin{tabular}{|c|c|c|c|c|c|c|c|}
\hline Order & Familiy & Species & Stage $^{+}$ & Part observed & Status & Site 1 & Site 2 \\
\hline \multirow[t]{5}{*}{ Orthoptera } & Gryllidae & Gryllus bimaculatus & Growth & Litter, soil & 0 & * & * \\
\hline & \multirow[t]{2}{*}{ Pyrgomorphidae } & Zonocerus variegatus & Growth & Leaf & $\mathrm{Ph}$ & * & * \\
\hline & & $\begin{array}{l}\text { Chrotogonus } \\
\text { senegalensis }\end{array}$ & Growth & Leaf & $\mathrm{Ph}$ & * & * \\
\hline & \multirow[t]{2}{*}{ Acrididae } & Locusta migratoria & Growth & Leaf & $\mathrm{Ph}$ & * & * \\
\hline & & Ochrilidia gracilis & Growth & Leaf & $\mathrm{Ph}$ & & * \\
\hline \multirow[t]{8}{*}{ Coleoptera } & \multirow[t]{2}{*}{ Cetoniidae } & Pachnoda marginata & Growth & Flower & $\mathrm{Ph}$ & * & * \\
\hline & & Diplognatha gagates & Growth & Flower & $\mathrm{Ph}$ & * & * \\
\hline & Scarabeidae & Phyllophaga sp. & Growth & Soil, root, stem & $\mathrm{Ph} ; \mathrm{D}$ & & * \\
\hline & Elateridae & Agriotes sp. & Flowering & Soil, stem, cob & $\mathrm{Ph} ; \mathrm{D}$ & * & * \\
\hline & \multirow[t]{2}{*}{ Tenebrionidae } & Eleodes sp. & Growth & Soil, stem, cob & $\mathrm{Ph} ; \mathrm{D}$ & * & \\
\hline & & Tenebrio molitor & Growth & Soil, stem, cob & & & \\
\hline & Cerambycidae & Cerambyx milles & Flowering & Leaf & $\mathrm{Pr}$ & & * \\
\hline & Coccinellidae & Cheilomenes sulphurea & Growth & Leaf & $\mathrm{Pr}$ & * & * \\
\hline \multirow[t]{2}{*}{ Hymenoptera } & Formicidae & Pachycondyla sylvestri & Growth & Soil, Leaf & $\mathrm{Pr}$ & * & * \\
\hline & Apidae & Apis mellifera & Flowering & Flower & $\mathrm{Ph}$ & * & * \\
\hline Diptera & Antomyiidae & Delia sp. & Growth & Soil, cob & $\mathrm{Ph} ; \mathrm{C}$ & * & * \\
\hline Homopterous & Aphididae & Rhopalosiphum maidis & Growth & Leaf, cob & $\mathrm{Ph} ; \mathrm{Vv}$ & |* & ${ }^{*}$ \\
\hline Heteroptera & Coreidae & $\begin{array}{l}\text { Pseudotheraptus } \\
\text { devastans }\end{array}$ & Flowering & Leaf & $\mathrm{Ph}$ & * & * \\
\hline
\end{tabular}




\section{Nandjui et al, J. Appl. Biosci. 2018 Impact of Soil Fertility Management Practices on Insect Pests and Diseases of Maize in Southwest Cote d'Ivoire}

\begin{tabular}{|c|c|c|c|c|c|c|c|}
\hline \multirow[t]{3}{*}{ Lepidoptera } & \multirow[t]{2}{*}{ Noctuidae } & Spodoptera littoralis & Flowering & Leaf, cob & $\begin{array}{l}\mathrm{Ph} \\
\text { (borer) }\end{array}$ & * & * \\
\hline & & Helicoverpa zea & Fructification & Cob & $\begin{array}{l}\mathrm{Ph} \\
\text { (borer) }\end{array}$ & * & * \\
\hline & Pyralidae & Eldana saccharina & Flowering & Leaf, stem, cob & $\begin{array}{l}\mathrm{Ph} \\
\text { (borer) }\end{array}$ & * & * \\
\hline Dictyoptera & Blattidae & Blatta sp. & Growth & Litter, soil & 0 & * & \\
\hline Isoptera & Termitidae & Microtermes sp. & Fructification & Root, stem & $\mathrm{Ph}$ & * & * \\
\hline 09 & 18 & 22 & & & & 19 & 20 \\
\hline
\end{tabular}

+ Stage of observation of the insect

$\mathrm{C}=$ Coprophage; $\mathrm{D}=$ Detritivores $\mathrm{O}=$ Omnivores $\mathrm{Ph}=$ Phytophagous $\mathrm{Pr}=\mathrm{Predator} ; \mathrm{Vv}=$ Virus vector.

\section{Krohon 1}

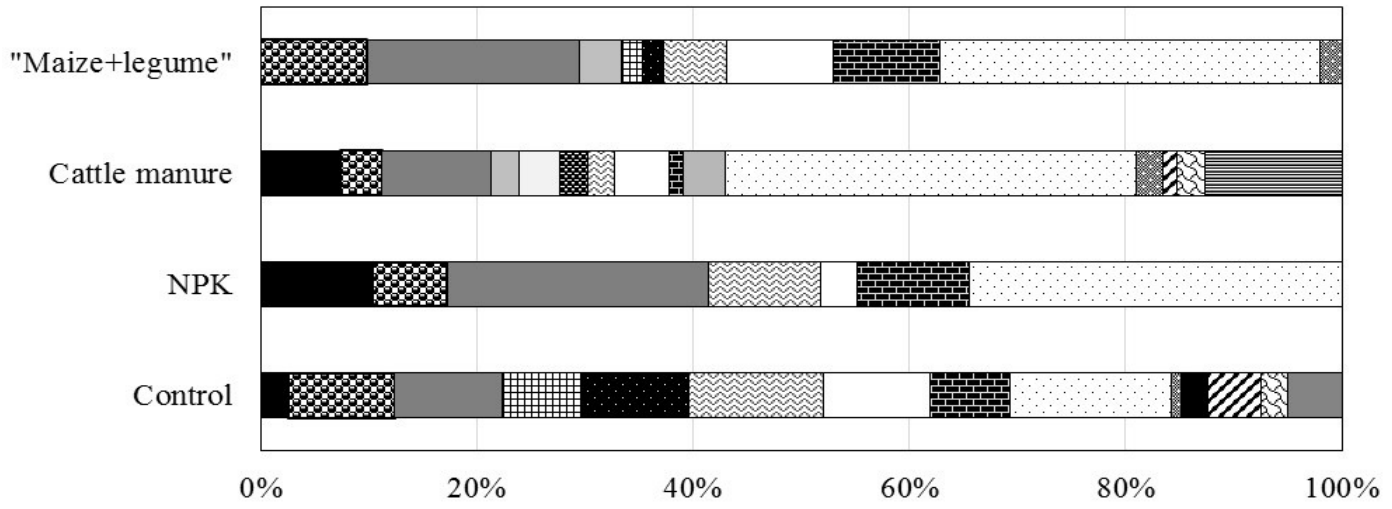

Krohon 2

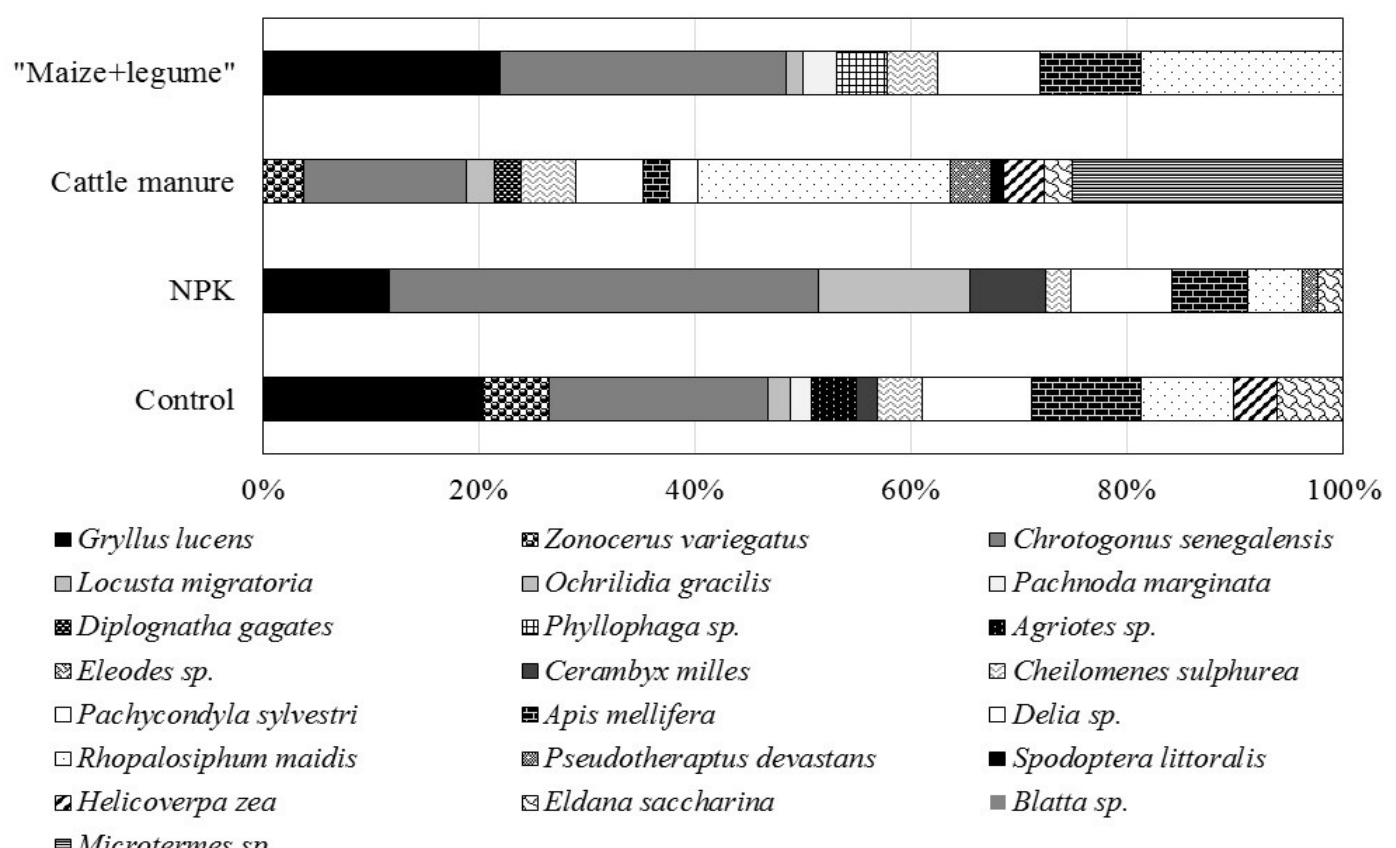

目Microtermes sp.

Fig. 2: Distribution of insect species collected at each site during all the production cycle 
Insect infestation: Significant differences $(p<0.001)$ were observed between leaf infestation rates. The highest leaf infestation rates were recorded under cattle manurefertilized plots $(26.50 \pm 0.79$ for Krohon 1 and $42.74 \pm$ 2.34 for Krohon 2). Besides cattle manure-fertilized plots, almost none significant difference was observed between the others plots (Fig. 3). Unlike leaf infestation rate, no significant difference $(p>0.05)$ was observed between stem infestation rates calculated for each treatment at each site. Stem infestation rate was comprehensively highest at Krohon 1 (Fig. 3).

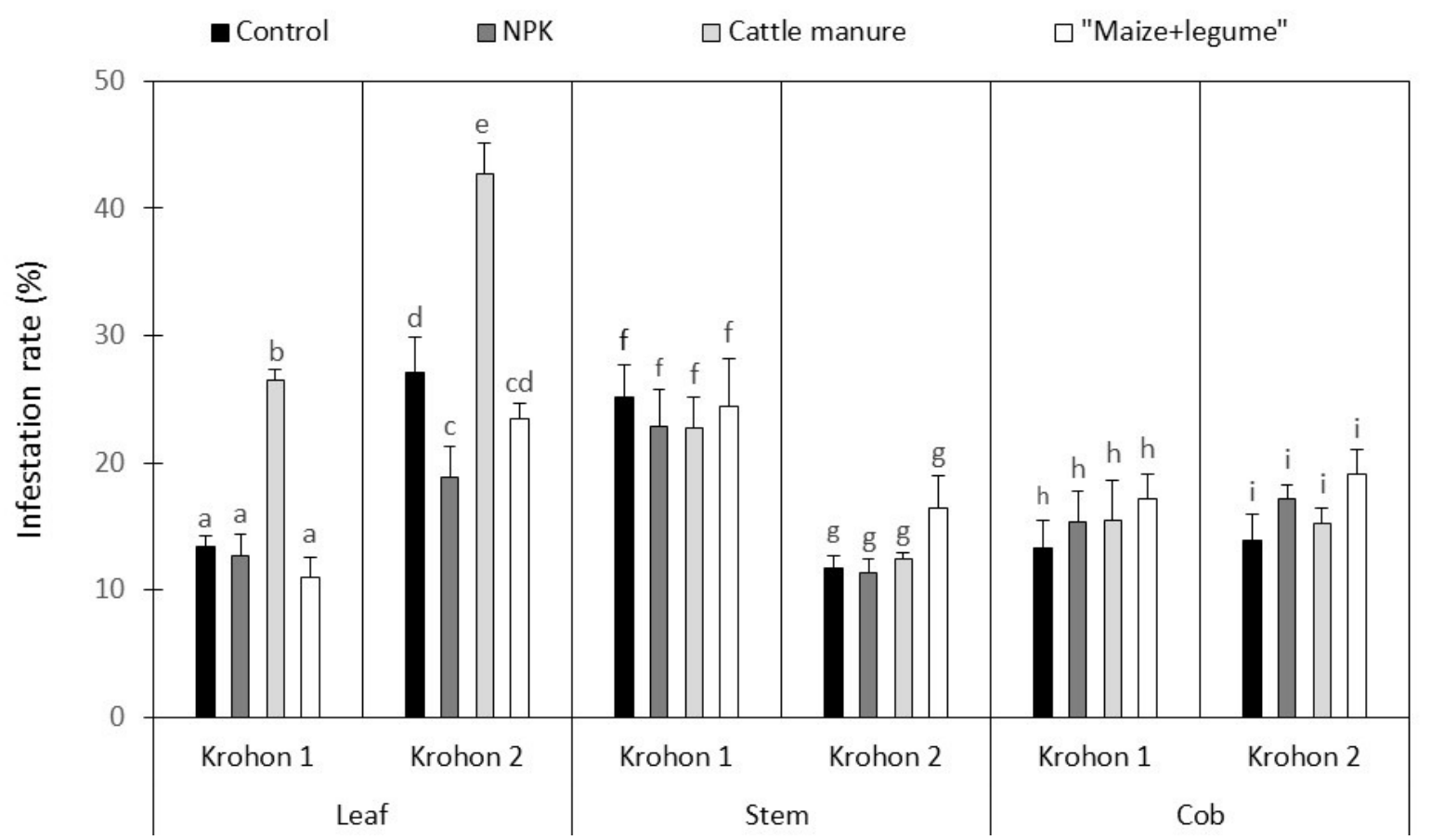

Fig. 3. Infestation rates of leaves, stems and corn cobs calculated per treatment for both sites.

Frequency of diseases: Two diseases (maize streak and curvularia leaf spots) were observed at both sites. Significant differences were observed according to maize streak disease frequency $(p<0.001)$. Cattle manurefertilized plots and "maize+legume" plots were more infected compared to the others treatments. However, plots of Krohon 1 were comprehensively more infected than those of Krohon 2: $7.05 \pm 0.62$ and $1.56 \pm 0.05$ respectively for cattle manure-fertilized plots. For curvularia leaf spots, no significant difference was observed (Fig. 4). 


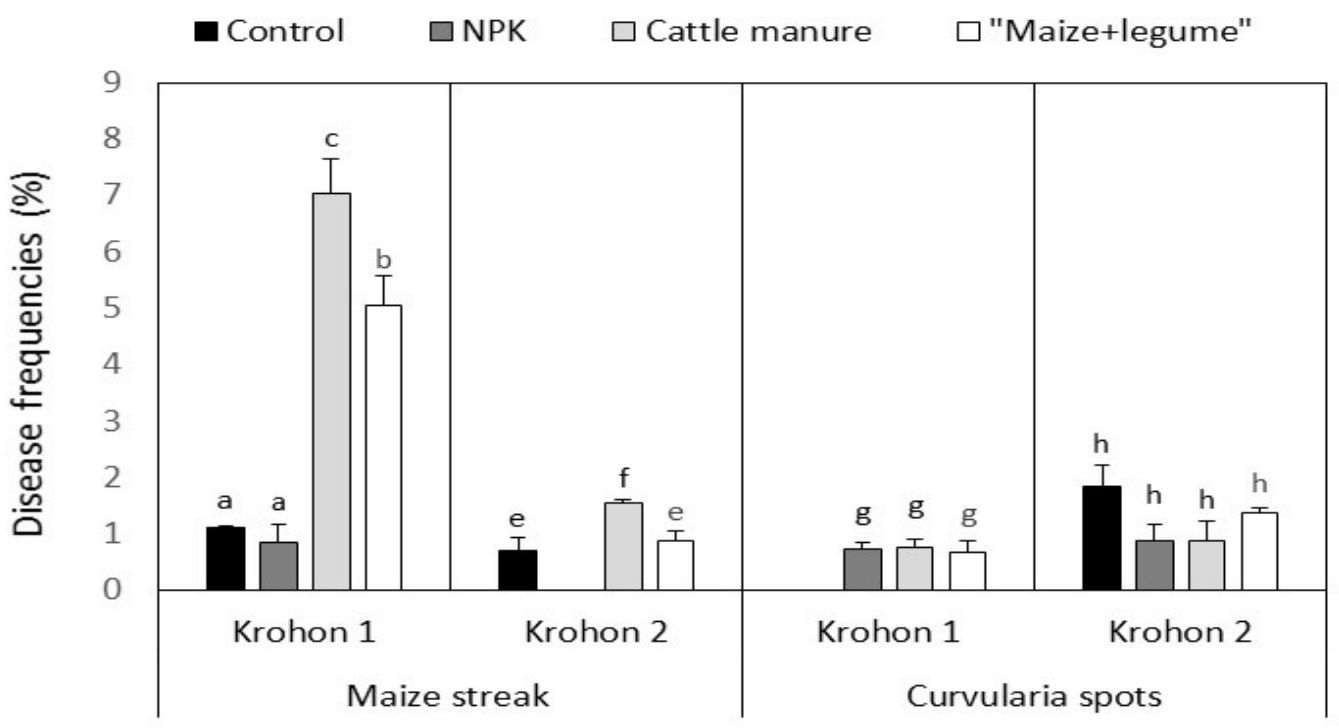

Fig. 4: Disease frequency recorded for each treatment at both sites.

Severity of diseases: Comprehensively, severity degree varied around 20 and $25 \%$ when the disease was observed. No significant difference was observed among treatments (Fig. 5).

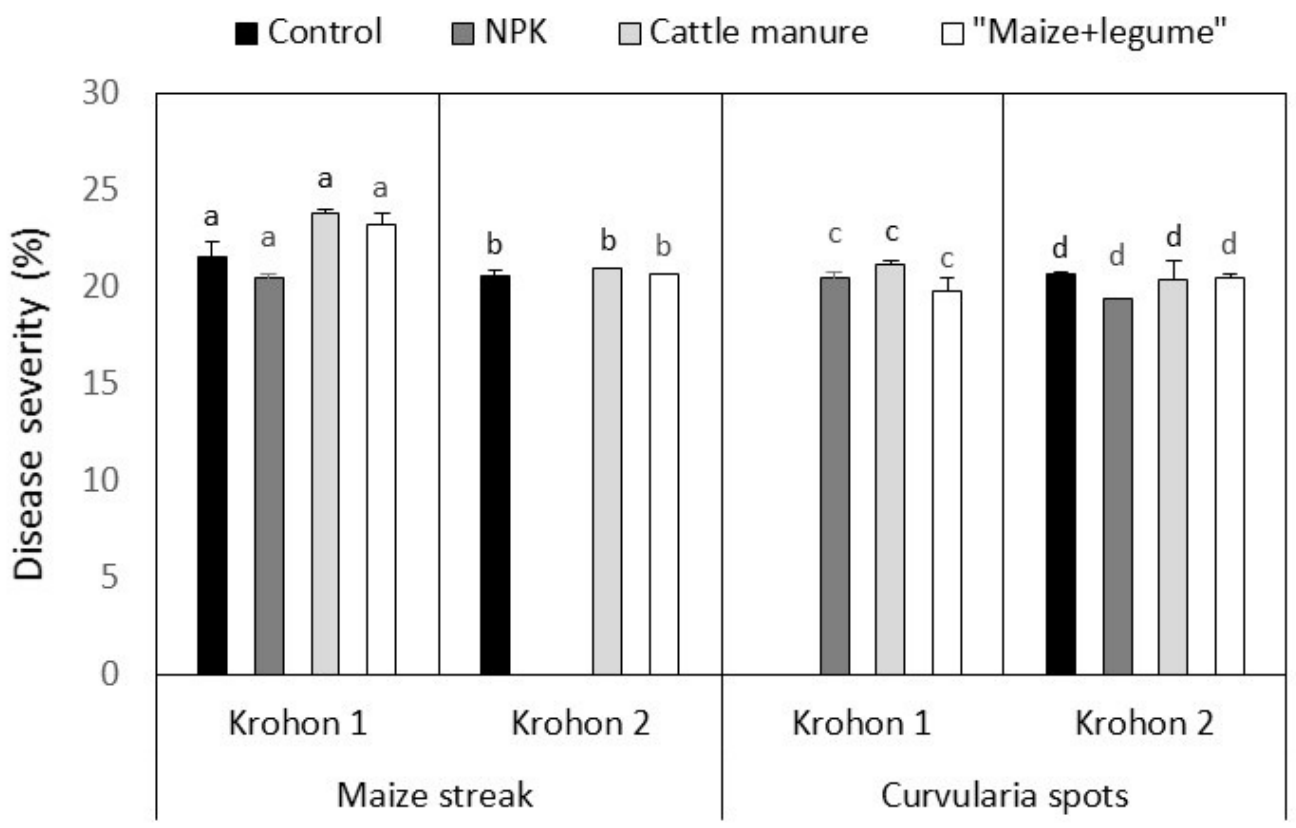

Fig. 5: Disease severity recorded for each treatment at both sites

Maize yields: All fertilization options significantly affected maize yields. Overall, no difference was recorded between maize yields recorded for the different fertilization option either in maize monocropping or in maize associated with legume (Fig. 6). 


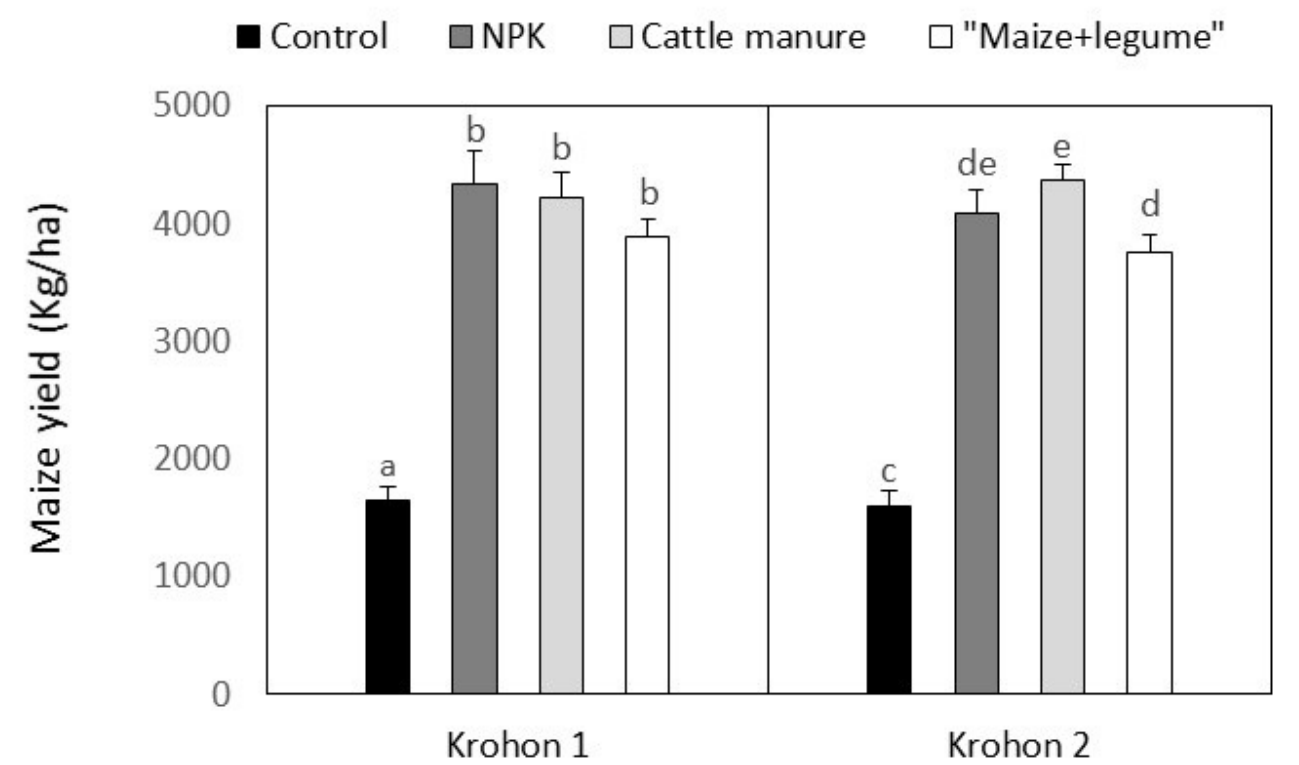

Fig. 6: Yields in dry matter (kg/ha) recorded as means \pm standard-errors during the second year experiment.

\section{DISCUSSION}

Significance of insects and diseases observed on maize during the trials: Maize was sensitive to a diversity of insects as indicated by Steffey et al., 1999 and Jean \& Boisclair (2009). Lepidoptera are more likely to cause damage to maize (Ortega, 1988; Kfir, 1997; Tafera et al., 2016). Among Lepidopteran pests known in Cote d'Ivoire, only $E$. saccharina was found in this study. The others pests are likely to be observed in the Nawa region, South West Côte d'Ivoire (Moyal, 1998). However, the setup of trials on April, could explain why these species were not observed. Indeed, their infestation in the study region is more probable between June-July, when the second generation of adults emerge after diapause (Moyal, 1998). In addition, insecticide applied four WAS probably allowed reducing insect's communities such as virus vectors and then virus transmission to plants (Goré Bi et al., 2011; Adja et al., 2014). Maize streak appears to be probably the main viral threat that reaches maize and curvularia leaf spots were repeatedly encountered in Côte d'Ivoire (Fauquet \& Thouvenel, 1987; Karavina, 2014). Several other diseases attack maize in Côte d'Ivoire. These two diseases observed bring out two hypotheses: (1) the study area would favour specifically these two of diseases; (2) the variety used was resistant to some diseases. Until now, no study inventoried maize diseases of the region and characteristics of maize variety used are still poorly known. However, it should be noted that observations were made after plant maturity so that some maize diseases (rust and helminthosporiasis) could not be observed (CIMMYT, 2004).

Effect of fertilization type on incidence of pest insects and diseases and yields: Agrosystems management impact insect's pests. According to Kfir et al. (2002), it was observed that, stem borers were marginally more prevalent in fertilized crops than in unfertilized crops. Fertilized crops could increase borer infestation and survival through an increase in plant nitrogen content. In this study, borers' attack was the same for all treatments suggesting that this attack was not influenced by soil fertilization management. In previous a study carried at in Brobo (savannah area in the Centre of Côte d'Ivoire) and Gagnoa (forest area in Southwest region) by Moyal (1993), the same result was observed. In this study, comparing various modalities of maize cultivation (pure vs intercropped with peanut, at high or low density and fertilization level), with good or bad weeding, and with or without protection against borers, no interaction between various factors was observed. The borer density was the same for any cultivation modality or weeding frequency. These results suggested that borer attacks, mainly by $E$. saccharina, are little influenced by environment (Moyal, 1993). For leaf infection rate, it was significantly affected by cattle manure. Several studies indicated that cattle manure would attract a large number of insects, namely Diptera, Lepidoptera, Coleoptera and Apidae. In addition, cattle dung could attract virus vectors that could explain 
the higher maize streak frequencies observed in organicfertilized plots (Bosque-Perez et al., 2000; Konaté et al., 1994). Field observations showed in addition that the use of cattle dung increase weed development. These weeds are mainly Poaceae (Imperata cylindrica, Panicum spp., Digitaria spp., Bracharia spp.) and appear as probable source of inoculum of Maize streak virus (MSV). Wild Poaceae are natural hosts of MSV and play important role in maize streak epidemiology (Konaté et al., 1994; Magenya et al., 2008). The range of MSV hosts was evaluated at 106 species of Poaceae (ICTVdB Management, 2006), including those observed in this study but not formally recorded. The symptom severity observed evolves considerably with the source of inoculum, and proportional to the abundance of the reservoirs (Konaté et al., 1994). These observations are therefore consistent with those made at both study sites. Cattle dung application requires additional weeding to limit weed populations. Despite the potential advantage of mixing crop related to better control of pests and diseases (Malézieux et al., 2009), no positive effect of mixing maize with legume was revealed in this study. From leaf and stem infestation by insect pest to maize streak and curvularia leaf spot, no clear evidence demonstrated positive/negative effect of mixing maize with beans or

\section{ACKNOWLEDGMENTS}

We are grateful to IITA that funded this study through the CGIAR program for Humid Tropics (Humidtropics). We also thank all R4D members for their contributions at

\section{REFERENCES}

Adja NA, Danho M., Alabi TAF, Gnago AJ, Zimmer J-Y, Francis F, Kouassi KP, Baudoin J-P, Zoro BIA, 2014. Entomofaune associée à la culture de cucurbites oléagineuses africaines (Lagenaria siceraria Molina (Standl. 1930) et Citrullus lanatus Thumb (Matsum and Nakai 1916) et impact des ravageurs sur la production. Annales de la Société Entomologique de France 50(4): $301-310$

Altieri MA and Nicholls $\mathrm{Cl}$, 2003. Soil Fertility management and insect pests: harmonizing soil and plant health in agroecosystems. Soil and Tillage Research 72(2): $203-211$.

Bordat D and Arvanitakis L, 2004. Arthropodes des cultures légumières d'Afrique de l'Ouest, central, Mayotte et Réunion. CIRAD, Montpellier.

Bosque-Perez NA, 2000. Eight decades of maize streak virus research. Virus Research 71: $107-121$. soybeans. It is difficult to explain the particularly high maize streak frequency observed on maize associated with soybeans at Krohon 1 . This effect of crop association on reducing the incidence of pests and diseases is not always true. The ability of some pests and pathogens to use a wide range of plants as alternative hosts/reservoirs is the main limitation to the suppressive role of this strategy, but all other pathways identified for the control of pests and disease based on plant species diversity also have certain limitations (Ratnadass et al., 2012). If airborne diseases can also be avoided to some extent through crop selection and crop rotations that include some non-host crops, this strategy is more effective for soil or residue-borne pathogens (Krupinsky et al., 2002, Gao et al., 2014). Insect responses to cues are not fixed but depend on the context, the physiological state of the insect and prior learning experiences (Bruce, 2015). Although biologists often study individual interactions of one species of insect with one species of plant, the reality in nature is more complicated because plants are exposed to multiple pest and beneficial organisms. Much less is known about the effect of multiple, co-occurring stress factors than individual biotic and abiotic stresses, despite the fact that multiple stresses are probably the rule under natural conditions (Bruce, 2015).

different stages of this study. Our gratitude also goes to all women's organizations for their high interest in the activities.

Bruce JAT, 2015. Interplay between insects and plants: dynamic and complex interactions that have coevolved over millions of years but act in milliseconds. Journal of Experimental Botany 66 (2): $455-465$.

$\mathrm{CABI}, 2015$. Pest and disease manual. Africa Soil Health Consortium. August 2015, Nairobi. ISBN (ebook): 9781780648194 .

CIMMYT. 2004. Maize diseases: A guide for field identification, fourth Ed. CIMMYT, Mexico.

Diby L, Kouassi G, N'Guessan MP, Yao E, Oro F, Aynekulu E, Kassin E, Kouame C, Coe R, Shepherd K, 2014. Cocoa Land Health Surveillance: An evidence-based approach to sustainable management of cocoa landscapes in the Nawa region, South-West Côte d'lvoire, Working Paper 193. Abidjan. DOI: http://dx.doi.org/10.5716/ WP14255. 
Fauquet C and Thouvenel J-C, 1987. Plant viral diseases in the Ivory Coast., second Ed., ORSTOM, Paris.

Gao X, Wu M, Xu R, Wang X, Pan R, Hye-Ji Kim H-J, Liao $H$, 2014. Root Interactions in a Maize/Soybean Intercropping System Control Soybean Soil-Borne Disease, Red Crown Rot. $\begin{array}{lll}\text { PLOS ONE 9(5): } & \text { e95031. }\end{array}$ doi:10.1371/journal.pone.0095031.

Goré, B.B.N., Baudoin, J.-P., Zoro, B.I.A., 2011. Effects of the numbers of foliar insecticide applications on the production of the oilseed watermelon Citrullus lanatus. Sciences et Nature. 8 (1), 53 62.

[Dataset] ICTVdB Management, 2006. Maize streak virus. Universal Virus Database, v4. http:// www.ncbi.nlm.nih.gov/lCTVdb/ICTVdB.

James B, Atcha-Ahowê C, Godonou I, Baimey H, Goergen G, Sikirou R, Toko M, 2010. Gestion intégrée des nuisibles en production maraîchère: Guide pour les agents de vulgarisation en Afrique de l'ouest. CTA/ITA, Ibadan.

Jean C and Boisclair J, 2009. Les insectes nuisibles et utiles du maïs: mieux les connaître. IRDA Ed, Québec.

Karavina C, 2014. Maize streak virus: A Review of pathogen occurrence, biology and management options for smallholder farmers. African Journal of Agricultural Research 9(36): 2736 - 2742.

Kfir R, 1997. Natural control of the cereal stem borers Busseola fusca and Chilo partellus in South Africa. Insect Science and its Application 17(1): $61-67$.

Konaté G, Traore O, Traore S, Esseh-Yovo MC, Markham P, Buduca C, Clerget B, Dintinger J, Rodier A, 1994. Maize streak, maize stripe and maize mosaic virus diseases in the tropics (Africa and islands in the Indian Ocean). Agriculture and Development, Special Issue, 55 -69 .

Kranz J. 1998. Experimental Techniques in Plant Disease Epidemiology. Kranz $\mathrm{J}$ and Rotem J (Editor), Springer-Verlag, New York, pp. 279 - 289.

Krupinsky JM, Bailey KL, McMullen MP, Gossen BD, Turkington TK, 2002. Managing plant disease risk in diversified cropping systems. Agronomy journal 94: 198 - 209.

Macauley H and Ramadjita T, 2015. Cereal Crops: Rice, Maize, Millet, Sorghum, Wheat. Background paper, Feeding Africa Conference, 21-23 October 2015, Dakar.
Magenya OEV, Mueke J, Omwega C, 2008. Significance and transmission of maize streak virus disease in Africa and options for management: A review. African Journal of Biotechnology 7 (25): 4897 4910.

Malézieux E, Crozat Y, Dupraz C, Laurans M, Makowski $D$, Ozier-Lafontaine $H$, Rapidel D, de Tourdonnet S, Valantin-Morison M, 2009. Mixing Plant Species in Cropping Systems: Concepts, Tools and Models: A Review. Lichtfouse $E$, Navarrete $M$, Debaeke $P$, Véronique S, Alberola C (Editors.), Sustainable Agriculture. Springer, Netherlands. pp. 329 353.

Michel B and Bournier J-P, 1997. Beneficials in Tropical Crops, first Ed, CIRAD, Montpellier.

Moyal $P, 1988$. Crop losses due to insects in savannah area of Ivory Coast: a review. Tropical Pest. Management, 34(4): 455-459.

Moyal P, 1993. Maize crop intensification and borer attacks in the Ivory Coast: insect populations. Paoletti MG, Foissner W, Coleman D. (Editors). Soil biota, nutrient cycling and farming systems. Lewis Publishers, New York, pp 253-265.

Moyal P. 1998. Les foreurs du maïs en Côte d'Ivoire: vers une protection intégrée. Agriculture and Development, 19, $16-27$.

Ortega AC, 1988. Insectes ravageurs du maïs: guide d'identification au champ. CIMMYT, Mexico.

Place $F$, Barrett $C B$, de Freeman $H A$, Ramisch $H A$, Vanlauwe $B, 2003$. Prospects for integrated soil fertility management using organic and inorganic inputs: evidence from smallholder African agricultural systems. Food Policy: 28, 365-378.

Pollet A. 1978. Les ravageurs du maïs en Côte d'lvoire. Données qualitatives et quantitatives pour la Basse Côte, ORSTOM, Paris.

Ratnadass A, Fernandes P, Avelino J, Habib R, 2012. Plant species diversity for sustainable management of crop pests and diseases in agroecosystems: a review. Agronomy for Sustainable Development: 32, 273 - 303.

Slaats JJP, Van der Heiden WM, Stockmann CM, Wessel M, Janssen $\mathrm{BH}$, 1996. Growth of the Chromolaena odorata fallow vegetation in semipermanent food crop production systems in South-West Côte d'Ivoire. Neth. Journal of Agricultural Science, 44: 179 - 192.

Smoot K., Gyau A, Kouame C, Diby L, 2013. Market analysis of selected agroforestry products in the Vision for Change Project intervention zone, 


\section{Nandjui et al, J. Appl. Biosci. 2018 Impact of Soil Fertility Management Practices on Insect Pests and Diseases of Maize in Southwest Cote d'Ivoire}

Côte d'lvoire. Working paper 174. Nairobi. DOI http://dx.doi.org/10.5716/WP13249.PDF.

Snapp S. 2002. Quantifying farmer evaluation of Technologies: The mother and baby Trial design. Bellon MR and Reeves J. (Editors.). Quantitative Analysis of Data from Participatory: Methods in Plant Breeding. CIMMYT, Mexico, pp. 9-16.

Steffey KL, Rice ME, All J, Andow DA, Gray ME, Van Duyn JW, 1999. Handbook of Corn Insects. Entomological Society of America, Lanham.

Tafera T, Mugo S, Mwimali M, Anani B, Tende R, Beyene Y, Gichuki S, Oikeh OS, Nang'ayo F, Okeno J, Njeru E, Pillay KM, Prasama BM, 2016. Resistance of Bt-maize (MON810) against the stem borers Busseola fusca (Fuller) and Chilo partellus (Swinhoe) and its yield performance in Kenya. Crop Protection, 89, 202 - 208.
Upton M, Mantle B, Hastings A, 2010. Methods for Collecting, Preserving and Studying Insects and other terrestrial arthropods, fifth Ed, Australian Entomological Society Miscellaneous.

Vanlauwe B, Bationo A, Chianu J, Giller KE, Merckx R, Mokwunye U, Ohiokpehai O, Pypers P, Tabo R, Shepherd KD, Smaling EMA, Woomer PL, Sanginga N, 2010. Integrated soil fertility management: Operational definition and consequences for implementation and dissemination. Outlook on Agriculture 39 (1): 17 $-24$.

Welz HG, Pernet AA, Pixley KV, Geiger HH, 1998. A gene for resistance to the maize streak virus in the African. CIMMYT maize inbred line CML202. Molecular Breeding 4(2): 147 - 154. 